\title{
Analysis of Low Realization For Mudharabah Financing at Muamalat Indonesia Bank, Banda Aceh
}

\author{
Arinal Rahmati ${ }^{1}$, Deni Mulyadi ${ }^{1}$, Januddin ${ }^{1}$ \\ ${ }^{1}$ Specialised Colleges of Syaria'ah Ummul Ayman Science in Pidie Jaya \\ tgkdrsaiful@gmail.com
}

\begin{abstract}
This study aims to determine the causes of low realization of mudharabah financing at Muamalat Indonesia Bank, Banda Aceh Branch. This research is expected to be a framework or model for other Islamic banks that have the same problem. Data for this study are collected through in-depth interviews and documentation studies. This research uses descriptive analysis method and the results of the data obtained are analyzed qualitatively. The results of the study show that the minimum factor of realization of mudharabah financing is caused by the bank's difficulty in obtaining the income statement accurately, transparently and routinely. In addition, mudharabah products are very vulnerable to the occurrence of moral hazard from business actors (mudharib) who tend to maximize profits resulting in reduced returns to the bank as shahibul mall. Then other factors are also influenced by the ineffectiveness of the profit-sharing financing model relating to entrepreneurs and the lack of interest in the scheme of profit sharing in business activities.
\end{abstract}

Keyword: financing; mudharabah; Muamalat Indonesia bank

\section{Introduction}

The development of Islamic economy that is increasingly prevalent in Aceh is a reflection and longing for Muslims, especially for traders, investors and even Islamic businesses which in Aceh are themselves regions framed in the realm of Islamic law. This also further supports the commitment of BI in the development of Islamic banks, especially in Aceh. It must be admitted that Islamic banks are an important part of people's economic development and also the majority of Muslims where the practice of Islamic banks is the answer to the anxiety of the Acehnese people about rampant usury.

Behind the rapid development of Islamic banks there is a phenomenon of neglecting its operational principles, namely profit sharing. This is indicated by the lack of results-based product implementation, namely mudharabah. It is precisely murabahah products that dominate the operations of Islamic banks. This is interesting to be explored considering the growth of Islamic banking in Indonesia is very rapid. In Aceh, banking assets in the fourth quarter of 2015 reached Rp. 43.49 Trillion, from the asset report conventional banking still dominated at Rp. 37.89 Trillion or $87.13 \%$, while the rest are Islamic banking assets of Rp. 5.6 Trillion or $12.87 \%$. Most of the assets are mostly channeled to financing products, which are around Rp. 27.23 trillion. this condition increased by $9.53 \%$ compared to the previous quarter of Rp. 26.37 Trillion or $7.6 \%$, this increase is in line with the decrease in the BI rate. ${ }^{\text {i }}$

The phenomenon of the lack of implementation of the profit sharing principle is shown from the fact that the mudharabah portion is small. According to Sharia banking statistics (SPS) issued by the Financial Services Authority (OJK) the number of mudharabah applications until 2015 reached $7.04 \%$ of the total funds. On the contrary in the same year Islamic banks actually practiced sale and purchase contracts which were not profit-sharing contracts. Evidence shows the large portion of murabahah financing per March 2015 was recorded at $58.47 \%$. ii

From these data illustrate that the operations of Islamic banks have not fully run as expected. Islamic banks should increase the share of mudharabah products, not just focus on 
buying and selling products. If examined in more detail, the advantages of Islamic banking are precisely the mudharabah and musyarakah products known as quasi equity financing which have an impact on economic stability. But it turns out that Islamic banks are less interested in offering mudharabah products fully, this is due to several things that need to get their own solutions. Therefore, the stigma of domination of murabahah products on the financing side, should have been reduced in portion and relocated to mudharabah and musyarakah financing.

With the description of the condition of the distribution of funds in Islamic banking in Aceh, as such, and allegedly contradictions with the objectives of Islamic banking are so noble, it becomes important and interesting to reveal further about the low realization of mudharabah financing at Bank Muamalat Indonesia with a research focus on the causes of low realization of mudharabah financing at Bank Muamalat Indonesia Banda Aceh Branch. Data for this study were collected through in-depth interviews and documentation studies. This research uses descriptive analysis method and the results of the data obtained are analyzed qualitatively.

\section{Review of Literature}

\subsection{Understanding Mudharabah and the Ability of the Contract}

Humans are creatures that interact socially and need each other. Some have excess assets but do not have the time and expertise to manage and develop them, on the other hand there are those who have skill skills but do not have capital. With the gathering of these two types of people it is hoped that they can complement each other and facilitate the development of these assets and abilities. For this reason, Islam allows companies in business including mudlārabah.

Islam syari'at cooperation contract mudharabah to facilitate people in collaboration because some of them have assets but are not able to manage it and there are also people who do not have assets but have the ability to manage and develop it. Shari'a allows this cooperation to benefit from one another.

Mudharabah comes from the word adh dharb fil ar'dhi, which is traveling for trade, which means trading and trading. The Hijaz people call Mudharabah with qiradh which comes from the word al-qardhu which means al-qardhu (deduction), because the owner of the funds deducts part of his property to be traded and gets a portion of profit, which is meant here one party issues a sum of money to the other party to manage and profit divided in two according to the agreement.

Besides that, etymologically mudharabah means walking on earth which is usually called traveling, this is in accordance with the word of God in QS. An-Nisaa 'verse 101 And when you travel on the earth, then why do not you qashar pray (thy). Whereas in terms of " mudharabah" contains the meaning of contract between the two parties, one party issues a certain amount of capital to the other party to be traded and profits are divided in two according to the agreement. Cooperation between capital owners (shahibul al-māl) and those who carry out productive business (mudlārib), that is what is called mudlārabah. ${ }^{i i i}$

In the world of Islamic banking, mudharabahh was introduced as a product for financing all capital needs in a business for a limited period of time according to agreement, net business results were divided between banks as funders and mudlārib as managers according to the agreement set forth in the contract, whereas if there this is caused not by negligence by the manager. And if the loss is caused by fraud or negligence by the manager, 
then the manager must be responsible or disadvantaged. ${ }^{\text {iv }}$ This is in line with what Mardani explained, where Mardani stated that if there is a loss, the owner of the capital will bear the provision that the loss occurs under normal circumstances, then the investor may not intervene with the user of funds in carrying out his business. ${ }^{\mathrm{V}}$

To make it easier for the reader the author makes an image like the one below

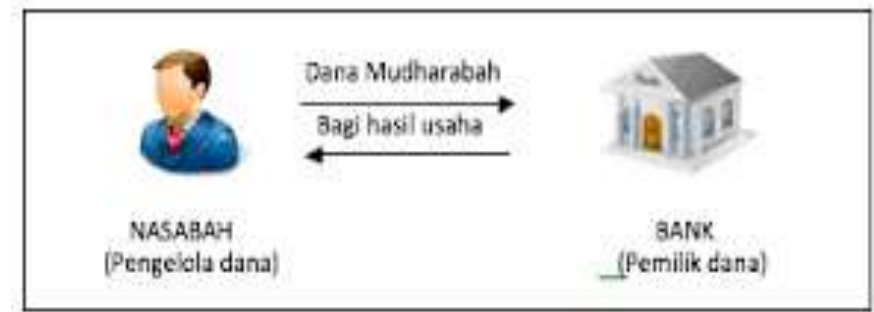

Islam allows mudlārabah agreement, because it aims to help each other between capital owners and capital managers on the basis of mutual help in managing a business, Islam provides an opportunity for both parties to work together. In general, mudlärabah legal basis reflects more advice to mankind to carry out business. ${ }^{\mathrm{vi}}$

The reason stated by the scholars of fiqh about the ability to cooperate is the words of Allah and the Prophet's hadith as follows:

\section{a. Al-Qur'an}

In Al-Quran that commonly used becomes the legal basis for the ability of this form of cooperation to be the word of God in several suras including the words of Allah SWT: QS. Al-Muzammil: 20, QS. Al Baqarah: 198, QS. Al-Jumu'ah verse 10

\section{b. Hadist}

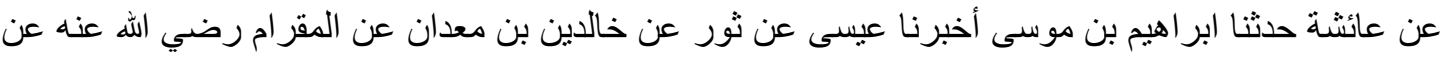

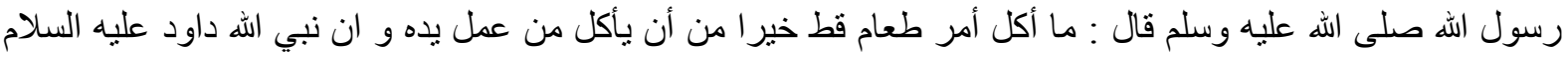

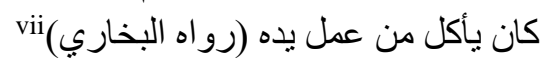

Meaning: "From Ayesha narrated by Ibrahim Bin Musa reported to us Isa and Khalid Bin Mu'dan from Muqarram ra, that the Prophet Muhammad said that whatever food is eaten by someone is better than the result of his own hand and how badly Prophet David ate except from the effort of his own hand (HR. Bukhari).

\subsection{Implementation of the Mudharabah Agreement on Islamic Banking}

The implementation of mudlärabah concept in Islamic banking is a contract of cooperation to carry out an effort between the two parties, namely the provider of capital or funds (shahib al-māl) and the party managing the business (mudlärib). The advantage of this product is to make it easier for people to cooperate because some of them have assets but are unable to manage it and there are also people who do not have assets but have the ability to manage and develop it. So that the Shari'a allows this cooperation to be able to benefit from one another. To facilitate the readers, the author lists the scheme as below: 


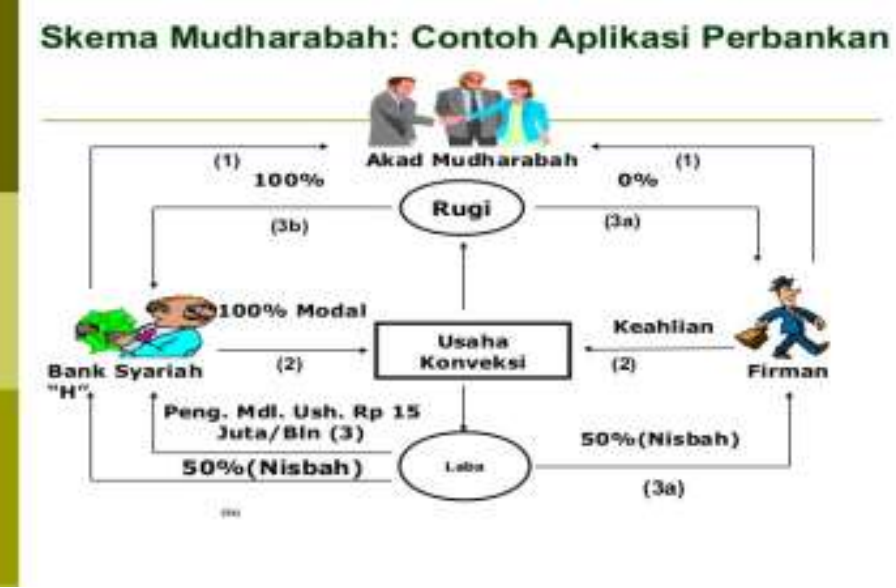

From the scheme it can be understood that there are parties who have funds in this case called banks, then there are others who do not have funds but have expertise, so the two groups of people meet to do business justified in Islam. Then the customer in this business or better known as mudhrib apply for financing in the form of mudharabah agreement. After a series of rules, terms and conditions agreed upon by both parties, they made an agreement contained in the contract. Furthermore, the bank provides 100\% capital to be managed by Mudarib. In the scheme the determination of the ratio is $50 \%: 50 \%$, while the loss is borne equally.

\section{Result and Discussion}

\subsection{Allocation of Mudharabah Financing at Bank Muamalat Indonesia} a. Assets of Bank Muamalat Indonesia Nasional

BMI is present as a bank that combines business idealism with spiritual values that underlie its operations. This harmony between business idealism and spiritual values is one of the advantages of BMI as an alternative to banking services in Indonesia. The Banda Aceh BMI is a bank based on the first syariah principles in Aceh. BMI's presence was welcomed by the people and the Aceh government. The purpose of establishing this bank is to create more equitable and guaranteed economic stability based on sharia principles.

The development of Islamic banking in Indonesia has become a benchmark for the success of Islamic economic existence. Marked by the presence of BMI. BMI is the first Islamic bank to become a pioneer for other Islamic banks in implementing the sharia system amid the proliferation of conventional banks today. The success of Islamic banks in implementing the system can be proven in the case of the monetary crisis that occurred in 1998, at which time Islamic banks were one of the banks that were still able to stand upright, even said to tend to grow rapidly faster. This was proven based on the annual BMI report data from 2011-2015 as in Table 1 below this:

Table 1 Development of Assets and Financing at National BMI in 2011-2015 (Trillion)

\begin{tabular}{|c|c|c|l|c|l|}
\hline No & Year & Asset & \multicolumn{1}{|c|}{ Financing } & \% & \multicolumn{1}{|c|}{ Growth } \\
\hline 1 & 2011 & $32,26 \mathrm{~T}$ & $22,46 \mathrm{~T}$ & 69,62 & $4,72 \%$ \\
\hline 2 & 2012 & $44,26 \mathrm{~T}$ & $32,86 \mathrm{~T}$ & 74,24 & $4,62 \%$ \\
\hline 3 & 2013 & $53,73 \mathrm{~T}$ & $41,80 \mathrm{~T}$ & 77,79 & $3,55 \%$ \\
\hline 4 & 2014 & $62,44 \mathrm{~T}$ & $43,11 \mathrm{~T}$ & 69,04 & $-8,75 \%$ \\
\hline 5 & 2015 & $57,17 \mathrm{~T}$ & $40,73 \mathrm{~T}$ & 71,24 & $2,2 \%$ \\
\hline
\end{tabular}




\section{Source: National BMI Annual Report 2011-2015}

In Table 1 above explains that whenever there is an increase in assets automatically the BMI will also increase the distribution of financing, which as stated in the table above. For example in 2011, BMI had assets of Rp. $32.26 \mathrm{~T}$, then channeled to a financing scheme of Rp. $22.46 \mathrm{~T}$ or $69.62 \%$. This figure decreased compared to the previous year (2010) of $4.72 \%$, or financing disbursement in 2010 amounted to $74.34 \%$ to $69.62 \%$ in 2011 . However, different conditions occurred in 2012, in which year National BMI has assets of Rp. $44.26 \mathrm{~T}$ is distributed for financing of Rp. $32.86 \mathrm{~T}$ or $74.24 \%$. This percentage is higher than in 2011 or increased by $4.62 \%$.

Furthermore, in 2013 along with the increase in assets, the BMI also increased funding distribution. Assets of Rp. 53.73 T is distributed for financing of Rp. $41.80 \mathrm{~T}$ or $77.79 \%$. If seen in the table above there is an increase in financing distribution of $3.55 \%$. But it is different from 2014, where assets grew but the BMI reduced the distribution of funding. Assets owned are Rp. $62.44 \mathrm{~T}$, channeled for financing of $43.11 \mathrm{~T}$ or $69.04 \%$. This figure decreased by $8.75 \%$ compared to the previous year (2013). For the year 2014 resulted in a decline in assets in 2015. Assets in that year amounted to Rp. 57.17 T is distributed at 40.73 $\mathrm{T}$ or $71.24 \%$. Despite the decline in assets, BMI increased its funding distribution by $2.2 \%$ to offset financing in the previous year (2014).

\section{b. Composition of Islamic Bank Financing}

The essence of mudlārabah to complement and mutually utilize fellow social beings, the need for cooperation between one party and other parties in order to improve the level of the economy and the necessities of life. Humans consist of various groups, namely the poor and the rich. On the one hand, many rich people are not able to manage and cultivate their property. On the other hand, many poor people are willing to work, but do not have the capital to run their businesses. Thus, the mudlārabah aims to fulfill the needs of both parties who need each other, namely for the benefit of humanity. To be more clear about the composition of the financing provided by Islamic Commercial Banks, see Table 2.

Table 2 Financing Composition provided by Sharia Commercial Banks (billion)

\begin{tabular}{|l|l|l|l|l|l|l|}
\hline Contract & $\mathbf{2 0 1 0}$ & $\mathbf{2 0 1 1}$ & $\mathbf{2 0 1 2}$ & $\mathbf{2 0 1 3}$ & $\mathbf{2 0 1 4}$ & $\mathbf{2 0 1 5}$ \\
\hline Mudharabah & $\mathbf{8 . 6 3 1}$ & $\mathbf{1 0 . 2 2 9}$ & $\mathbf{1 2 . 0 2 3}$ & $\mathbf{1 3 . 6 2 5}$ & $\mathbf{1 4 . 3 5 4}$ & $\mathbf{1 4 . 1 3 6}$ \\
\hline Musyarakah & 14.624 & 18.960 & 27.667 & 39.874 & 49.38 & 51.721 \\
\hline Murābahah & 37.507 & 56.365 & 88.004 & 110.565 & 117.371 & 117.358 \\
\hline Istisna & 347 & 326 & 376 & 582 & 633 & 651 \\
\hline Ijarah & 2.341 & 3.839 & 7.345 & 10.991 & 2011.6 & 11.386 \\
\hline Qard & 4.731 & 12.957 & 12.090 & 8.371 & 5.965 & 5.459 \\
\hline Total & 68.181 & 102.655 & 147.505 & 184.122 & 199.330 & 200.712 \\
\hline
\end{tabular}

Source: Statistics of Islamic Banking from 2010-2015

From these data it can be concluded that from 2010-2015 financing for Islamic banks was still dominated by the murābahah contract. The distribution of funds for murabahah is very different compared to other financing amounts. For mudhrabah and musad agreements and other contracts in Islamic banks, they are far below murabahah. the phenomenon of the low level of financing in the profit sharing scheme is an important issue that must be studied, the right solution is needed to increase revenue sharing financing in Islamic banking, 
especially at the Bank Muamalat Indonesia Banda Aceh Branch. The implications of the high non-profit-sharing financing or buying and selling products, namely mudaraba, make the community paradigm about the performance of Islamic banks. This risk is feared to cause cynicism among the public that the Islamic banking business is only a name change. Then supported by the goal of the formation of Islamic banking in Indonesia, namely: not to maximize profits as a banking system based on interest, but rather to provide socio-economic benefits to Muslim people

Murabahah domination which is the "determining factor" that influences the failure of Islamic banks in terms of increasing institutionalization based on social Mashlahah, because it has been used as a basic instrument in the transformation process from being a capitalistic financial institution. As a form of financial transaction, which is legally recognized by economic and Islamic law.

\subsection{Analysis of Low Realization For Mudharabah Financing}

The method of financing or funding of mudharabah as a new paradigm in the practice of sharia banking nationally is in fact far below the funding pattern or murabahah funding. Indeed, in fiqhiyah as well as in terms of regulations or banking legal rules, as well as the orientation of Islamic banking policies that prioritize murabahah funding patterns cannot be blamed, because the policy is inseparable from calculating a number of risks. Mudharabah financing is a manifestation of mutual risk and responsibility as a form of collectivism. Of course this is very different from the conventional bank paradigm that emphasizes the aspect of capitalism.

It turns out that the phenomenon of the low implementation of mudharabah contracts on Islamic banks is not only valid in Indonesia. The same thing happened in the world. This can be proven from several survey results, it turns out that syari'ah banks in general, apply a lot of murabahah as their main financing method, covering approximately $75 \%$ of their total wealth. Since the beginning of 1984, in Pakistan, financing for murabahah types accounted for around $87 \%$ of total financing in PLS deposit investments. Meanwhile, in Dubai Islamic bank, murabahah financing reached $82 \%$ of total financing during 1989 . In fact, at the Islamic Development Bank (IDB), for more than ten years the financing period was $73 \%$ of all financing was murabahah. In fact, the Shari'ah bank actually has a superior product, which is based on and loss sharing (PLS), namely mudharabah and musyarakah. ${ }^{\text {vii }}$

The same condition also occurred at Bank Muamalat Indonesia, Banda Aceh Branch. Assets in 2015 as listed in table 1.1. Rp. 57.17 T of the amount of the asset, amounting to Rp. 385.75 billion or $0.67 \%$ are assets of the BMI of the Banda Aceh Branch. In addition, BMI is one of the sharia banks which mostly allocates funds to the financing of Rp. 177 billion or $49.56 \%$ of total assets. For the portion of the murābahah financing itself, the funds disbursed amounted to Rp. 60,113 billion or $33.82 \%$ of the total funding distributed to 594 customers or $54 \%$ of total customers. Unlike the case with mudharabah products, or better known as the profit sharing scheme, the funds distributed were only 3,682 billion or $2.07 \%$. If examined further, not only in terms of distribution of funds, even in terms of the number of customers far more murabahah customers, for example in the case of murabaha products there are 594 customers, while for mudharabah products there are only 16 people. ${ }^{\text {ix }}$

The lack of realization of mudharabah financing is due to the risks inherent in the product itself. When compared to other products, mudaraba has a far higher risk than other products. The risks include bank difficulties in obtaining income statements accurately, 
transparently and routinely. In addition, mudaraba products are profit and loss sharing-based products that bring together Shahibul Mall and Mudarib, so that it is very vulnerable to the occurrence of moral hazard from business actors (mudharib) who tend to maximize profits resulting in reduced returns to banks as shahibul mall. Then other factors are also influenced by the ineffectiveness of the profit-sharing financing model relating to entrepreneurs and the lack of interest in the scheme of profit sharing in business activities. ${ }^{\mathrm{X}}$

The risk uncertainty faced by Islamic banks in using the principle of profit sharing does not mean that this principle is less marketable. To provide convenience for Islamic banks in providing funds to entrepreneurs through the principle of profit sharing, a Guarantor Institution needs to be established. This kind of condition actually illustrates the existence of a contradiction that must be sought for improvement. Community economic empowerment is believed to be able to spearhead economic growth. Through the brave and creative souls of entrepreneurs or aspiring entrepreneurs, creativity and added value will be created in the economy. However, this effort to improve entrepreneurship is clearly an effort that requires the availability of capital or funds, requires reliable human resources, as well as togetherness and mutual responsibility with others.

To reduce the possibilities of the risks mentioned above, Islamic banks need to apply a number of specific policies when distributing mudharabah financing, which is known as the distribution of mudharabah financing is one of the efforts of community economic empowerment believed to be able spearhead in economic growth. Through the brave and creative souls of entrepreneurs or aspiring entrepreneurs, creativity and added value will be created in the economy. However, this effort to improve entrepreneurship is clearly an effort that requires the availability of capital or funds, requires reliable human resources, as well as togetherness and mutual responsibility with others. Therefore, the stigma of dominance of murabahah products on the financing side, should have been reduced in portion and relocated to mudharabah financing.

This is where Islamic banking should play a more important role. How should Islamic banking be willing and able to encourage the birth of entrepreneurs by opening up access for them to develop their entrepreneurial spirit. But in the realization of Islamic banking it seems impotent. At least this is evidenced by the low realization of mudharabah financing by Islamic banks, whereas mudharabah is the potential spearhead of economic empowerment. Mudharabah can give birth to new entrepreneurs, or increase the role of old entrepreneurs. In practice Islamic banking actually likes to act more so that it can be safe and fast to foster profits.

Therefore, in terms of the objectives of Islamic banking itself as stated in the Handbook of Islamic Banking, it is stated that the basic purpose of Islamic banking is to provide financial facilities by seeking financial instruments in accordance with the provisions and norms. sharia norm. ${ }^{\mathrm{xi}}$ and Islamic banks are different from traditional banks in terms of their active participation in the socio-economic development process of Islamic countries. It is stated in the book that the main purpose of Islamic banking is not to maximize its profits as an interest-based banking system, but rather to provide socio-economic benefits to Muslims.

On the contrary, some of the Muslim bankers assumed that the role of Islamic banking was solely commercial, based on interest-free financial instruments and aimed at generating financial benefits. In other words, Muslim bankers do not assume that an Islamic banking is a social institution. ${ }^{\text {xii }}$ 
In an interview conducted by Kazarian, Dr. Abdul Halim Ismail, manager of the Islamic bank of Malaysia Berhard, stated that "as an obedient Muslim business, my goal as manager of the bank (Islamic Bank of Malaysia Berhard) was merely to seek the highest possible profit without using financial instruments which is based on interest." "xiii

As for the advantages of mudharabah compared to murabahah There are at least seven potential benefits that differentiate in the case of social Mashlahah ${ }^{x i v}$ : First, in Islamic banks mudharabah has the power and authority that is more in determining the condition of the project compared to murabaha where the essence of murabahah is limited to the bank in providing commodity goods, therefore, muduhabah is more effective related to social problems.

Second, Mudharabah is claimed to be able to strongly encourage the real economy of the sector, because institutions have a direct relationship with real market conditions. The reason is that in the results-based contract, real economic activists occur which prioritize the principles of fairness and honesty. The parties involved in this contract have obligations and rights that are commensurate with their performance. Unlike murabaha, which limits their operations to direct transactions. These two mechanisms, if properly implemented, will eat Islamic banks that are truly related to trade, the real sector, and different types of commodities and can be involved with projects and their customers to propose their projects that will trigger creativity.

Third, Mudharabah is more suitable in terms of risk sharing among partners of investment projects and thus reducing risks for them. For this mechanism, inherently makes it impossible for both sides of the risk-free transaction because in mudharabah, which in the investor bears all losses and

Fourth, in murabahah as an exchange contract is the definition of one transaction, unlike other types, which are based on partnerships and projects. Thus, lately it is more suitable to include various mechanisms such as ijarah, rent, and istisna 'and salam, which means that they have more potential to produce social effects.

Fifth, mudharabah helps realize the potential in terms of supporting people who have knowledge and skills but do not have sufficient financial resources. Similarly, greetings and istisna that help producers who do not have enough capital accumulation to carry out their own projects; and ijarah which makes it possible to use commodities without buying for those who want to do it.

Sixth, an important element of the Islamic financial system, which has important implications for social cooperation and solidarity is the type of Islamic insurance called "takaful." Parallel to the insurance agreement, this mechanism consists of three main elements, including partnerships, mobilizing financial resources, and the risk of sharing losses. Therefore, this can fulfill social functions.

And finally, most Islamic financial institutions that exclusively focus on murabahahbased mechanisms have become somewhat like capitalistic banks, they have had a number of problems in terms of maintaining the principles of Islamic sharia.28 So that they have a major obstacle in finding the necessary support from the wider community projects that are based on community welfare. 


\section{Conclusion}

Based on the above assessment, it can be concluded that the implications of the low realization of the distribution of mudharabah financing make the community paradigm about the performance of Islamic banks. What is feared will cause cynicism among the public that the Islamic banking business is only a name change. Then supported by the goal of the formation of Islamic banking in Indonesia, namely: not to maximize profits as a banking system based on interest, but rather to provide socio-economic benefits to Muslim people. Syari'ah banking should be willing and able to encourage the birth of entrepreneurs by opening access for them to develop their entrepreneurial spirit. Which as it is known that the distribution of mudharabah financing is one of the efforts of populist economic empowerment believed to be able to spearhead economic growth. Through the brave and creative souls of entrepreneurs or aspiring entrepreneurs, creativity and added value will be created in the economy.

\section{References}

' Bank Indonesia. Kajian Ekonomi dan Keuangan Regional Provinsi Aceh, Bab III "Perkembangan Perbankan Daerah dan Sistem Pembayaran"., hlm. 50-52.

i Otoritas Jasa Keuangan, Statistik Perbankan Syariah, Maret 2015,. hlm. 30

iii M. Umar Chapra, Al-Qur'an Menuju Sistem Moneter Adil, (Yogyakarta: Dana Bhakti Prima Jasa, 1997), hlm. 44.

iv Abdul Azis Muhammad Azzam, Nidzam al-muamalat fi al-fiqh al-islami, edisi Indonesia Fiqh Muamalat Sistem Transaksi Dalam Fiqh Islam , (Jakarta : Hamzah, 2010), hlm, 245.

${ }^{\vee}$ Murdhani, Fiqh Ekonomi Syariah (Jakarta: Kencana, 2012), hlm. 195.

vi Muhammad Syafi'i Antonio, Bank Syari'ah dari Teori ke Praktik, (Jakarta: Gema Insani Press, 2001), hlm. 95.

vii Imam Abi Abdillah Muhammad ibn Ismail ibn Ibrahim ibn Mughirah ibn Bardisbah alBukhari, Shahih al-Bukhari, (Beirut: Darul Kutub Alamiah, 1992), Juz. 2, hlm. 6.

viii Anita Rahmawaty, Ekonomi Syariah: Tinjauan Kritis Produk Murabahah Dalam Perbankan Syariah Di Indonesia. Jurnal Ekonomi Islam, La Riba, Vol. 1, No. 2, Desember 2007.

ix Data internal Bank Muamalat Indonesia cabang Banda aceh.

${ }^{x}$ Interview with Mr. Suhardi, Relationship Manager Remedial Bank Muamalat Indonesia cabang Banda Aceh, pada tanggal 13 Juni 2016

${ }^{x i H a n d b o o k}$ of Islamic Banking diterbitkan dalam bahasa Arab oleh The Intitutional Association of Islamic Banks di Kairo dalam enam Jilid. Uraian dalam tulisan ini dikutip dari Sutam Remy Syahdeini dari Ellias G. Kazarian, (Jakarta: UI Press, 1996), Hlm. 54-61.

xii Dalam Pasal 3 Undang-Undang No.21 Tahun 2008 dinyatakan bahwa Bank Syariah, di samping menjalankan fungsi komersial, juga melaksanakan fungsi sosial di bidang Baitul Maal, Zakat, Wakaf dan lain-lain

xiii Abdullah Ghofar, Regulasi Bank Syariah Dalam Pendekatan Ilmu Hukum Dan Sistem Perbankan. Jurnal Ilmu Hukum Kenotariatan, repertorium. Vol. 1 juni 2010

xiv Ismail Cebeci, (2012),"Integrating the social maslaha into Islamic finance. hal 177 